\title{
THE RELATIONSHIP BETWEEN CLASSROOM MANAGEMENT AND STUDENTS' LEARNING: A SYSTEMATIC REVIEW
}

\author{
Araştırma Makalesi / Research Article
}

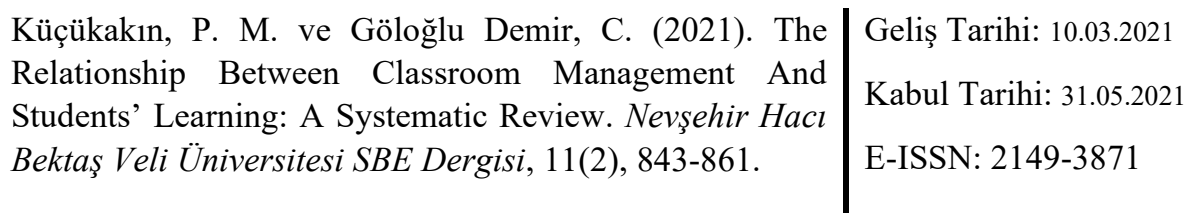

Öğr. Gör. Dr. Pınar Mercan KÜÇÜKAKIN

Ankara Yıldırım Bayezit Üniversitesi, Yabancı Diller Yüksek Okulu mercan.pinar@hotmail.com

ORCID No: 0000-0002-6966-0555

Dr. Öğr. Üyesi Cennet GÖLOĞLU DEMİR

Bandırma Onyedi Eylül Üniversitesi, Sağlık Bilimleri Fakültesi gologlu.cennet@gmail.com

ORCID No: 0000-0002-8770-6107

\begin{abstract}
In the contemporary classrooms, teachers need to facilitate productive learning environments in which students can develop necessary skills and competencies to thrive in the 21 st century. Establishing a productive and positive learning environment is a challenging task for the teachers as there are various factors affecting actual classroom activities that may result in effective or ineffective teaching (Hardin, 2011; Weinstein \& Novodvorsky, 2015). How effectively the students learn and improve their skills and how well they behave are affected by a teacher's ability to manage different aspects of the classroom (Oyinloye, 2010). Within this framework, the main purpose of the present study was to synthesize the qualitative research studies on classroom management conducted between 2009 and 2019. It was also aimed to investigate the relationship between classroom management and students' learning by examining the current perspectives and practices of classroom management. In order to synthesize the qualitative data on classroom management and to generate common themes with respect to learning and classroom management, content analysis of main findings of the analyzed studies was carried out. The synthesis of the reviewed studies indicated that different dimensions of classroom management and learning were studied extensively in relation to four themes: "positive learning environment", "physical environment in the classrooms", "management of learning tasks and instructional activities", and "motivation and academic engagement". A synthesis of current perspectives and practices of classroom management in the literature may contribute to provide solutions for the educational/learning problems, if any, stemming from ineffective classroom management implementations. Our findings might also provide teachers with practical insights to improve the quality of teaching and learning in their classrooms.
\end{abstract}

Keywords: Classroom Management, Positive Learning Environment, Instructional Activities, Motivation, Academic Engagement.

\section{SINIF YÖNETIMİ VE ÖĞRENME ARASINDAKİ İLISSTKI: SISTEMATIKK BİR İNCELEME}

\section{ÖZ}

Çağdaş sınıflarda öğretmenler, öğrencilerin 21. yüzyılda başarılı olabilmeleri için gerekli beceri ve yetkinlikleri kazanmalarına olanak sağlayacak verimli öğrenme ortamı oluşturabilmelidir. Sınıfta verimli ve olumlu bir öğrenme ortamı oluşturabilmek öğretmenler için zorlu bir görevdir çünkü gerçek sınıf ortamında öğrenmeyi olumlu ya da olumsuz şekilde etkileyen çeşitli faktörler vardır (Hardin, 2011; Weinstein \& Novodvorsky, 2015). Öğrencilerin ne kadar etkili öğrendiklerini, becerilerini ne kadar iyi geliştirdiklerini ve sınıfta ne kadar iyi davranış sergilediklerini belirleyen en önemli faktörler arasında öğretmenin sınıf yönetimi becerileri yer almaktadır (Oyinloye, 2010). Bu çerçevede, bu çalışmanın temel amacı, 2009-2019 yılları arasında sınıf yönetimi konusunda yapılan nitel çalışmaları sistematik bir şekilde değerlendirmektir. Ayrıca, sınıf yönetimi ile öğrencilerin öğrenmesi arasındaki ilişkinin, sınıf yönetimine dair güncel bakış açıları ve uygulamaları incelenerek araştırılması amaçlanmıştır. Sınıf yönetimi ile ilgili nitel verilerin sistematik bir şekilde sentezlenmesi ve öğrenme ve sınıf yönetimi ile ilgili ortak temaların oluşturulması amacıyla incelenen araştırmaların ana bulgularının içerik analizi yapılmıştır. Yapılan sistematik değerlendirmenin sonuçları sınıf yönetimi ve 
öğrenmenin dört ana tema çerçevesinde incelendiğini göstermiştir: "olumlu öğrenme ortamı”, "sınıfın fiziksel ortamı”, “öğrenme görevlerinin ve öğretim etkinliklerinin yönetimi” ve "motivasyon ve akademik katılım”. Alanyazındaki sınıf yönetimi ile ilgili güncel bakış açıları ve uygulamalarının bir sentez çalışmasının yapıllması, etkisiz sınıf yönetimi uygulamalarından kaynaklanan eğitim/öğrenme sorunlarına çözüm getirilmesine katk1 sağlayabilir. Araştırmanın sonuçları öğretmenlere sınıf uygulamalarını şekillendirecek ve eğitim öğretim faaliyetlerinin kalitesini arttıracak fikirler verebilir.

Anahtar Kelimeler: Sınıf Yönetimi, Olumlu Öğrenme Ortamı, Öğretim Faaliyetleri, Motivasyon, Akademik Katılım

\section{INTRODUCTION}

In the contemporary classrooms, teachers need to facilitate productive learning environments in which students can develop necessary skills and competencies to thrive in the 21st century. How effectively the children learn and how well they behave are affected by a teacher's ability to manage different aspects of classroom (Oyinloye, 2010). A well-managed classroom enables the teachers to build good relationships with their students as well as to maintain a better instruction and organization in the classroom. Classroom management covers whole spectrum of management tasks carried out by a teacher. The teacher's effectiveness in classroom management and instruction lies in his/her ability to maximize the time spent on academic activities such as participating in the lessons and working on assignments and minimizing the time spent on non-academic or less academic activities like waiting for the activities to start, transitions between activities, sitting without anything to do or engaging in misconduct (Weinstein \& Novodvorsky, 2015). Even if it is possible learn the components of effective classroom management and instruction, creating an effective teaching and learning climate in real classroom environment is a challenging task for the teachers as there are various factors affecting classroom activities that may result in effective or ineffective teaching (Hardin, 2011; Weinstein \& Novodvorsky, 2015).

The educators have encountered an increase in the undesired student behavior due to the enrichment of the stimuli in the learning-teaching environment, and the transformations of needs, interests and expectations of the individuals as a result of social and educational changes (Demir, 2009). The new role of the teacher in the 21 st century classroom requires changes in teachers' classroom management approach. In order to manage classroom activities and to meet individuals' needs simultaneously in the classroom, a teacher needs to be knowledgeable in diverse areas. The teacher needs to have the competence to create the setting, decorate the room, develop rules and communicate those rules to pupils, speak to children and listen to their responses and to put routines in place. Moreover, teacher is responsible for giving pupils the deserved attention even if it is apparently difficult to do so, given that varying needs of different students arise at the same time in the same class. The teacher's ability to perform the required skills will determine the achievement and behavior of students (Khan, Khan \& Majoka, 2011; Oyinloye, 2010).

The undesired student behavior which hinders the flow of the lesson and spoils the learningteaching environment is an indicator of an important problem in classroom management. For many teachers, problematic behaviors of students is one of the most crucial threats for education and learning as it causes a significant waste of time and has an adverse effect on learning process. A teacher with good classroom management skills needs to have developed not only the skills to elicit students' cooperation in minimizing misconduct and the skills to intervene effectively in the case of a misconduct, but also the skills to ensure that academic activities are taking place more or less continuously and that management system in the classroom is set up in such a way to maximize student participation in these activities. For this reason, any classroom management procedure needs to be made during and in between the completion of classroom activities in a way that supports the continuity and effectiveness of these activities, which means that the activities themselves must be planned and implemented effectively during the lesson. Effective management interventions enhance students' engagement in academic activities, while not disrupting the flow of the activities themselves (Manning \& Butcher, 2003; Walters \& Frei, 2007).

\subsection{Theoretical Framework and Related Research Studies}

To Martin and Sugarman (1993, p.9) "classroom management refers to those activities of teachers that create positive classroom climate in which effective teaching and learning can occur." 
According to Evertson and Weinstein (2006) classroom management had two purposes (1) the development of an orderly environment so that academic learning can take place and (2) the promotion of students' social-emotional learning. Teacher management of pupil behavior should be distinguished from teacher control or management of learning task. Management of learning tasks refers to the practices like selection of learning activities and materials and evaluation of performance. It deals with the degree of students' freedom and responsibility for self-directed learning in contrast to teacheroriented learning (Weinstein \& Novodvorsky, 2015).

The terms classroom management and discipline are often used interchangeably, but they have different meanings. Discipline is related with the structures and rules for student behavior and ensuring that students obey the rules. While discipline is an agent that shapes, corrects and inspires appropriate behavior, classroom management is an umbrella term which refers to teacher's capability and effort of handling a range of activities in the classroom such as learning, social interaction and student behavior. In other words, discipline is just a single aspect of classroom management, which is a broader concept (Martin \& Yin, 1997; Oyinloye, 2010). Martin \& Baldwin (1992) defines classroom management as a multidimensional procedure comprising three broad components; person, instruction and discipline. Teachers' belief about students constitutes the person dimension while instructional dimension includes the activities which result in learning such as performing classroom routines, physical arrangement and time management. On the other hand, discipline dimension incorporates teachers' actions aimed at setting and enforcing standards for students' behaviors.

\subsection{Classroom Management Approaches}

Understanding teachers' perceptions regarding classroom management stands to be an important issue as teachers have divergent beliefs concerning classroom management which influence the effectiveness of instruction. In the same way, there is a strong link between teachers' attitudes and beliefs towards classroom management and their classroom management implementations (Oyinloye, 2010). Glickman and Tamashiro (1980) put forward a framework to give an explanation about teacher beliefs concerning classroom management in terms of three approaches, i.e., interventionist, noninterventionist, and interactionalist. According to this model, interventionist approach is based on the assumption that human development is influenced by external environment (people and facilities) which justifies teachers' complete control (Martin \& Baldwin, 1992; Walfgang \& Glickman, 1980 as cited in Djigic \& Stajiljkovic, 2011). Interventionists hold the view that teacher-generated rewards and punishments are the driving forces behind learning the appropriate ways of behavior. This suggests a high level of teacher control over classroom activities and procedures.

On the other hand, non-interventionists believe that a person needs to express and accomplish his unique needs and the teacher should have minimal control (Martin \& Baldwin, 1992; Walfgand \& Glickman, 1980 as cited in Djigic \& Stajiljkovic, 2011). According to this approach, students possess an inner drive that needs to reflect itself in the real world. For this reason, the students should be given the freedom to exercise significant impact on the classroom procedures and teachers should be less active in adjusting their behaviors (Glickman \& Tamashiro, 1980). As far as the interactionalists are concerned, students acquire the appropriate ways of behaviors by interacting with the outside world of people and objects. Thus, students and teachers should have an equal say in setting the grounds for classroom management (Glickman \& Tamashiro, 1980).

\subsection{Research Studies on Classroom Management}

The research studies on different dimensions of classroom management revealed that an effective classroom management results in effective instruction and higher student achievement in particular (Freiberg, Huzinece \& Templeton, 2009; Martin \& Baldwin, 1992). The studies on classroom management examine teachers' perceptions regarding different dimensions of classroom management with respect to certain variables such as gender, experience and achievement level of students. Foxworthy (2006) found out that teachers' beliefs regarding classroom management changed as they gained more insights and knowledge through experience. Martin and Baldwin (1992) and Laut (1999) found out that experienced teachers were less authoritarian in terms of their classroom management approaches. Martin, Yin and Mayall's study (2006) revealed significant differences with respect to experience and gender. While experienced teachers scored significantly more controlling than less experienced teachers, females scored more interventionist than males. On the other hand, Khan, Khan, 
and Majoka (2011) investigated the gender differences in classroom management strategies adopted by secondary school teachers. This study revealed that male teachers were more authoritarian compared to female teachers. Moreover, female teachers had more serious problems in managing their classrooms as compared to male teachers.

There are also many studies which examine dimensions of classroom management in relation with different variables such as academic achievement, inclusive pedagogic strategies and effective learning environment. In his study which investigated the teachers' classroom strategies for inclusion, Kurawa (2010) analyzed classroom management implementations of teachers as a part of inclusive pedagogic strategies. This study revealed that teachers shared the responsibility for classroom management with the students in order to inculcate a sense of belonging and self-discipline in students. Moreover, Freiberg, Huzinec and Templeton (2009) examined the achievement effects of a prosocial classrooms and instructional management program-Consistency Management and Cooperative Discipline (CMCD). The study indicated that involving students in meaningful ways in management of their classrooms, a central point of CMCD, yielded to student achievement. Discipline and more learning time were found to have improved the conditions that lead to greater learning outcomes.

Classroom management, which increases teacher effectiveness, is an important part of teacher training programs. Teacher candidates' perceptions and practices of classroom management are mostly shaped through classroom management courses. The reviewed studies revealed different findings regarding the impact of teaching methods and instructional strategies applied in classroom management courses. In their research study, Akar and Yildırım (2009) examined the conceptual change in teacher candidates' perceptions in constructivist learning environment in a classroom management course. The study showed that there was a move from control-oriented images towards learning-oriented images in teacher candidates' understanding of classroom management thanks to constructivist learning process. As an alternative model of teaching about classroom management, Brocato (2009) investigated student teachers' views of studio-based learning. Its effectiveness for person-centeredness and for fostering better thinking about classroom management was also explored. The study revealed that the use of a propose-critique-iterate process helped create a better, more person-centered teaching in terms of classroom management, and thus, lead to a better an improved understanding of classroom management (Brocato, 2009). Lastly, Mader (2009) examined the perceptions of his students regarding removal of instructor grading in a classroom management course. The study demonstrated that upon removal of instructor grading in a graduate course, the teachers attained, in classroom management terms, a new vision of the connection between good teaching, good learning, and good management. Many promised to substitute their use of external incentives with instruments that aim at more meaningful instruction. Being authentically involved in their own learning of classroom management without any concerns for the final grades, learners' interest in the topic was enhanced. In regard to struggles, while some students reported their weakness in setting personal goals for learning, some others stated that they experienced difficulties in deciding if they really deserved the grade they would give themselves. The follow-up study revealed that the experience altered teachers' prior assumptions in a positive way, improved their practices in classroom management, and had a positive effect on their overall professional growth.

Definitions of classroom management in the literature emphasized the relationship between classroom management and students' learning and academic achievement. Prior studies also revealed the ways classroom management affected students' learning. Informed by previous research, our study addresses the need for a study which examines the relationship between classroom management and students' learning through a systematic analysis of qualitative research studies so far lacking in the literature. A synthesis of current perspectives and practices of classroom management in the literature may contribute to provide solutions for the educational/learning problems, if any, stemming from ineffective classroom management implementations. Our findings might also provide teachers with practical insights to improve the quality of teaching and learning in their classrooms. Within this context, the main purpose of the present study was to synthesize the research studies on classroom management conducted between 2009 and 2019. It was also aimed to investigate the relationship between classroom management and students' learning by examining qualitative findings revealed by research studies published in the last decade.

This systematic review aimed to answer the following questions: 
1) What kinds of common themes emerge in the findings of the reviewed studies?

2) What are the main findings of reviewed studies with respect to classroom management and students' learning?

\section{METHOD}

According to Bearman et. al (2012), systematic review is a valuable methodology which enables researchers to have an access to a quality synthesis of research and provides meaningful implications for policy and practice. A systematic review process necessitates a detailed analysis and comparison of research studies following explicit criteria. In this paper, research studies on classroom management were analyzed to examine the relationship between classroom management and learning. The research was carried out through Internet databases. All education databases of EBSCOHOST service were searched through METUnique Search. To make the results more compatible with the purposes of the present study, the research was narrowed down via using specific keywords. Descriptors used and the number of the studies found, were as follows: "Classroom management/in the title" and "learning/ subject term": 253; "Classroom management/in the title" and "motivation/subject term": 54; "Classroom management/in the title" and "misbehavior/subject term":6. As it was seen that initial search did not include some studies potentially important for the present study, searches were expanded by using new key words: "qualitative/ all text" and "Classroom management/ in the title" and a total of 302 studies were found.

After completing the initial search, retrieved studies were listed and duplications were removed. Upon the process of categorization based on the scope of the study, 21 studies were chosen for the present analysis (See Appendix A for detailed information about reviewed studies). In summary, selection of the studies to be included in the present systematic review was conducted based on the following criteria:

\section{Inclusion Criteria}

- Studies published between 2009-2019 were included

- Studies published in peer-reviewed journals were included.

- Studies carried out at K-12 level were included.

- Case studies, action research and design based research studies providing qualitative data were included.

- Studies investigating classroom management practices of student teachers in real classroom environment were included.

\section{Exclusion Criteria}

- Survey studies were excluded.

- Any review studies were excluded

- Studies whose full-texts were not accessible were excluded.

- Any studies carried out at tertiary level were excluded.

- Any studies carried out at private courses were excluded.

- Any studies conducted in online and filliped classrooms were excluded.

- As the focus of this study was to examine the relationship between classroom management and learning, the studies which did not provide data regarding students' learning were excluded.

- Studies whose language was other than English and/or Turkish were excluded.

- Studies conducted in classroom management course offered to student teachers were excluded. In order to synthesize the qualitative data on classroom management and to generate common themes with respect to learning and classroom management, content analysis of main findings of the analyzed studies was carried out. At the first stages, learning related findings were highlighted and 
categorized by the researchers. For an effective and reliable data analysis, content of each paper was studied several times and findings concerning students' learning were extracted, interpreted and classified into thematic categories individually by the two authors. Comparison of these categories and themes between the first and second authors resulted in over $90 \%$ agreement. Findings are presented in the generated thematic categories.

\section{FINDINGS}

The synthesis of the reviewed studies indicated that different dimensions of classroom management and learning were studied extensively in relation to four themes "positive learning environment", "physical environment in the classrooms", "management of learning tasks and instructional activities", and "motivation and academic engagement".

\subsection{Positive Learning Environment}

A teacher may not be able to teach successfully unless she/he creates and maintains a wellstructured, productive and positive learning environment (Weinstein \& Novodvorsky, 2015). Establishing and maintaining positive learning environment was illustrated as an important dimension of classroom management in the reviewed studies. In their research study Paliç \& Keleş (2011) investigated the perceptions of primary and secondary school teachers regarding classroom management. Their study revealed that teachers working at both levels were mainly concerned about positive climate in the classroom. They emphasized the role of caring about students, and maintaining good communication with students for classroom management. Moreover, primary school teachers pointed out the importance of giving emphasis on the 'student's personal development' while the secondary school teachers mentioned concepts of 'avoiding negative criticism' and 'calling the students with their names' (Paliç \& Keleş, 2011). In a parallel way, Ersozlu and Cayci (2016) found that when the teacher lacks effective communication skills, students' academic achievement levels decrease.

Effective teaching and learning take place in a well-managed and positive learning environment which is maintained by classroom management activities of teachers (Manning \& Butcher, 2003). Research studies analyzed for this review also revealed similar findings concerning the effect of positive learning environment on learning (Arın, Kızılaslan Tunçer \& Demir, 2017; Kubat \& Dedebali, 2018). In a study conducted by Baker, Gentry and Larmer (2016), novice teachers who participated professional development sessions on classroom management stated that they benefited from strategies for establishing relationship with students as creating a positive environment helped their students become better learners.

Kubat and Dedebali (2018) investigated perceptions of Science teachers regarding classroom management. They found out that effective classroom management was associated with creating a welcoming and democratic classroom environment, and establishing rapport with students. Participating teachers emphasized the importance of having positive attitudes towards students and they highlighted importance of "smiling" and "calling the students with their names. Similarly, Arın, Kızılaslan Tunçer and Demir (2017) found out that teachers perceived having effective communication skills and creating a positive climate in the classrooms based on mutual respect between students and teachers as important classroom management skills.

Reviewed studies also revealed that establishing relationship is challenging for the teachers because of diverging reasons and they need support to improve their skills to create a positive climate in their classrooms. Akın, Yıldırım and Goodwin (2016) investigated Turkish elementary teachers' perceptions of classroom management and classroom management problems they experienced. They found out that teachers characterized classroom management by collaborative activities in which students are involved in decision making and assigned responsibilities. The positive conception of classroom management was associated with creating a caring and respectful classroom environment and a sense of belonging. It was found out that teachers adjusted their classroom management orientations towards constructivism and made use of classroom management practices to create a caring and democratic learning environment and to establish relationships with students based on love and trust. However, it was challenging to establish relationship for the teachers because of the fights and complaints of students, jealousy among students for teacher's care, and difficulty in ensuring an equal distance in relationships with all students. 
Similarly, in their study Lew and Nelson (2016) examined classroom management practices of novice teachers. Their research study revealed that even if they perceived themselves competent in classroom management, novice teachers are in need of professional support to implement principles and strategies to establish relationships and build a community of learners who respect each other. The findings of the same study highlighted a gap between teacher education curriculum and real school practices. Majority of the participant stated that teacher education program enabled them to learn basic principles of classroom management. However, they expressed that they needed higher number of hands-on, micro-teaching opportunities to put the strategies and skills they had learned into practice in actual classroom settings.

The discrepancy between teacher education programs and real classroom practices was highlighted by another study conducted by Hildenbrand and Arndt (2016). They investigated classroom management practices of student teachers who completed certification in elementary and special education. Their research indicated that mismatch between education philosophies of student teachers which were shaped at teacher education programs and school wide education philosophies created difficulties for the student teachers while implementing positive classroom management strategies. Namely, being educated about the best practices in management and observing poor strategies being implemented was challenging for the student teachers. There was a mismatch between proactive, positive, student-centered classroom management strategies they had learned at teacher education programs and the reactive, punitive and teacher-centered strategies they observed in real classrooms.

\subsection{Physical Environment in the Classrooms}

Physical environment in classrooms is integral component of classroom management as it affects how teachers and students think, feel and behave and impact student engagement and learning process. Creating a comfortable pleasant physical environment shows the learners that the teacher cares and respects them (Weinstein \& Novodvorsky, 2015). The reviews studies revealed important findings with respect to impact of physical environment on students' learning process. Akar et. al (2010) carried out a research on teachers' classroom management approaches and experiences and discovered that improper physical environment in the classroom interfered with the effective use of materials in students centered activities. On the other hand, Broome's case study (2013) revealed that group seating facilitated peer assistance and collaboration during studio production and cleanup sessions in the new art room designed for effective learning. Social contact and interaction were also reinforced by empty spaces and circulated seating arrangement in the classroom. Similarly, in Poon, Tan and Tan's study (2009), seating arrangement, having fairly equal number of boys and girls at each table was found to decrease off-task behaviors.

Modifying the classrooms and designing new learning environments contributed to student learning by increasing academic engagement and psychological well-being and by decreasing disruptive behavior (Broome, 2013; Guardino \& Fullerton, 2010; Kubat \& Dedebali, 2018). Guardino and Fullerton (2010) carried out a case study to explore the effect of modifications in classroom environment on academic engagement and disruptive behavior in an inclusive classroom. Their study indicated that academic engagement and classroom behavior were positively influenced by the modifications in the classroom environment such as changing the seating arrangement, creating group space, creating clear pathways in areas of high congestion, adding plants and inspirational posters, providing chair bags to hold supplies needed for academic and sponge activities and study carrels for each student. Broome (2013) also found out that creating a psychologically pleasing classroom was enabled by designing inviting and comforting classroom environment through using materials with softness and color and the provision of natural light, transparency and elements of nature. Similarly, Akın, Yildirım and Goodwin (2013) found out that adjustments and regulations teachers applied to make the physical environment more orderly, clean and comfortable helped students become academically more engaged and affected classroom management positively. Lastly, Hildenbrand and Arndt's study (2016) indicated that student teachers were reluctant to make environmental changes to improve the learning environment even if they were aware that small touches to classroom décor was needed. Realizing that classroom management strategies they had learned in teacher education program were in contrast with classroom realities was a real challenge for student teachers. 


\subsection{Management of Learning Tasks and Instructional Activities}

Management of learning tasks and instructional activities which refer to teachers' ability to maximize academic engagement and minimize the time spent on non-academic or less academic activities is another determinant of effective classroom management (Brophy, 1988). Oyinloye (2010) asserted that teachers believed that effective teaching and learning took place in well managed classroom and they needed to employ different instructional methods engaging the low achievers in the activities and meeting their diverging needs. Instructional management keep the students focused on learning tasks and minimize behavior problems. Teachers who demonstrate effective instructional behaviors keep the students focused on learning task and minimize behavior problems. Reviewed studies also indicated that effective instructional management is a good preventive strategy and resulted in better-behaved students (Manning \& Butcher, 2003).

The reviews studies presented management of learning tasks and instructional activities as an important dimension of classroom management. In Lew and Nelson's study (2016), participating teachers emphasized the relationship between classroom management and instructional planning and the importance of keeping students on task for an effective classroom management. Similarly, Merç and Subaş1 (2015) found out that ineffective instructional behaviors of the teachers such as implementing poor teaching methods and using insufficient and inadequate materials created classroom management problems. In another study by Akan and Basar (2013), effective implementation of instructional activities which increased participation and reinforced collaboration among students helped the teacher with classroom management.

In this context, Poon, Tan and Tan (2009) carried out an action research to examine useful strategies employed by a sixth grade teacher in managing her inquiry based classroom. In their study, it was shown that use of hands-on, minds-on activities engaged learners as they were both enjoyable and challenging making students think and find solutions on their own. With the help of group-based activities the participating teacher could manage to prepare the equipment and materials for students to use in their investigations in an easier way. In this study, organizing resources for discovery activities was found effective in hindering off-task behaviors of students. An important result regarding off-task behavior was revealed by Vors and Gal-Petitfaux's study (2015) which investigated academic learning time in physical education and classroom management strategies of teachers working in a compensatory education setting. Their study revealed that learning activity may consist of inseparable on-task and offtask behavior. When their occasional off-task behaviors are not tolerated, "difficult" students have conflict with the teacher

\subsection{Motivation and Academic Engagement}

Another important principle of classroom management is that learners' motivation to learn increases in well-managed learning environments. Effective classroom management strategies enhance academic engagement and reduces problem behaviors in the classrooms (Webster-Stratton et. al, 2011; Kunter, Baumert \& Köller, 2007). Motivation as a key to classroom management was also highlighted in the reviewed studies. To start with, in a study conducted by Akar et. al (2010) showed that classroom rules and routines hindered misbehaviors and maximized learning opportunities. Similarly, teachers utilized activities to know children personally and made plans to arouse curiosity for the subject matter in order to enhance effective learning and to motivate students. On the other hand, Demir (2009) found out teachers could not attract the attention of the learners or motive them as they did not adapt their classroom teaching to facilitate the classroom management and to form an effective classroom atmosphere.

Reviewed studies also indicated that moderate levels of classroom management results in positive classroom outcomes and increased academic engagement. Collier Meek, et al., (2019) evaluated the effects of teachers' implementation of best classroom management strategies on classwide academic engagement. Findings of their study suggested that positive classroom management strategies that the teachers implemented increased learners' academic engagement. More specifically, "references to schedules and routines" and "behavior specific praise" increased academic engagement while "error corrections" were found to decrease academic engagement. Practices of the teachers which lead to autonomy and full engagement of the learners impact the classroom management practices to a great extent. Akın, Yildırım and Goodwin (2013) also found out that instructional planning and 
implementation of classroom activities promoting student centeredness, active involvement and collaboration among student increased students' engagement and it became easier to manage the classroom. In this context, Mader (2009) examined the role of self-grading to remove external incentives and to increase intrinsic motivation in a classroom management course. The study indicated that the removal of instructor's grading influenced learning and management in a positive way by creating a meaningful learning environment. Students expressed that self-grading enabled them to see their weaknesses in setting personal goals for learning and to question their roles as learners. Being involved in their learning process authentically, students' motivation and engagement were increased and their interest for the lessons was enhanced. Similarly, Poon, Tan and Tan (2009) discovered that use of reflection during learning process enabled the students to build shared values in the classroom and also increased the motivation to cooperate with the teachers. Thus, students regulated their behaviors and warned one another in case of disruptive and off-task behaviors.

Bosch (2006) pointed out that classroom management is not a condition but a process. Namely, teachers need to modify classroom management skills and strategies in alignment with changing needs of their students. In this context, use of technology in classrooms brings divergent challenges to the learning environments which necessitates the application of different classroom management strategies and methods to enhance motivation and engagement of the learners. The use of technology is linked to classroom management and students' motivation to learn in the reviewed studies (Boyac1, 2010; Erdoğan et. al, 2010). Boyacı (2010) examined the perceptions of pre-service teachers regarding webbased classroom management. Student teachers expressed that classroom management in web-based classroom brought an extra workload and its effectiveness was associated with teachers' roles. In webbased classroom settings, teachers were considered as guides or mentors with competency on technological issues, subject area knowledge, interaction skills and motivational skills. Moreover, student teacher thought web-based instruction was motivating for the learners because its flexibility in terms of time and place. Similarly, Erdoğan et. al (2010), investigated classroom management and discipline problems that Information Technology lessons teachers faced and aimed to find out underlying reasons and possible solutions to these problems. Their research study revealed that participants thought that increasing engagement of learners would provide solutions for the classroom management and discipline problems in Information Technology lessons. For this aim, teachers were proposed to improve their pedagogical and subject area knowledge and use activities to facilitate motivation. To hinder undesirable internet surfing during the lessons the use software programs was recommended. Similarly, involving students in the process of setting the classroom rules was another solution offered by the participants.

\section{CONCLUSIONS AND IMPLICATIONS}

This review aimed to synthesize the research studies carried out on classroom management in the last ten years to investigate the relationship between classroom management and learning. To this end, the present study provided a general picture of the contemporary views and practices of classroom management by presenting a synthesis of the current studies in the field. After qualitative synthesis of review data, we have extracted four major themes about classroom management: "positive learning environment", "physical environment in the classrooms", "management of learning tasks and instructional activities", and "motivation and academic engagement". We presented our conclusions and related recommendations in line with the emerged themes:

(1) Review of the studies concerning classroom management revealed common themes which provide implications for improving teaching and learning in the classrooms. In relation to positive learning environment, the analysis revealed that classroom management was mostly associated with the creation of a positive learning environment. Well-managed, positive learning environments resulted in effective teaching and learning while effective learning environments lead to both student engagement and acquisition of desired behaviors. Previous research also revealed that the positive learning environment ensured students involved as active participants of teaching and learning process (Djigic \& Stajiljkovic, 2011), enabled students to improve their learning skills efficiently (Saeed, 2009) and contributed to acquisition of desired behaviors (Garrett, 2008; Yıldırım \& Dönmez, 2008). Therefore, it can be suggested that practitioners improve their skills and strategies to ensure effective learning environments in their classrooms which minimize the classroom management problems and maximize learning opportunities. For this reason, while setting the classroom rules and routines, teachers need to 
pay attention to the contextual characteristics such as learner differences and background, classroom social climate, inclusive pedagogies, and cultural features of their own local context. In this way, it becomes possible to employ the most appropriate strategies and methods creating positive and productive learning environments in their classrooms. Lastly, existence of disparities between teacher education and real classroom practices was an outstanding result of this research. In this sense, teacher education programs should equip student teachers with sound knowledge and necessary skills about how to create a positive learning environment in their classrooms as it was found one of the factors interfering novice teachers' classroom management.

(2) As for the physical environment, it was revealed that students' learning process and their behaviors were also shaped by the physical environment in the classroom. The studies indicated that designs and physical features of the classrooms influenced learning by increasing learners' engagement and psychological well-being and by decreasing disruptive behavior. Furthermore, improper physical environment hindered effective use of materials and carrying out certain activities. In this context, United Nations Educational, Scientific and Cultural Organization [UNESCO] (2012) stated that physical characteristics of the classroom such as furniture, temperature, space and light, and social learning environment of the classroom influence learning process. In this framework, it can be said that while designing the classrooms, it is important to consider functional and physical features of the classroom setting. It necessitates being aware of the environmental characteristics of the classroom, and arranging the physical environment to meet instructional purposes and to meet the unique needs of the learner group.

(3) Another dimension of classroom management addressed in the reviewed studies was related to the management of learning tasks and instructional activities. The review indicated that teachers needed to utilize well-designed learning tasks through use of appropriate instructional methods and strategies. Such kind of activities contributed to increasing time spent on academic tasks, facilitating learner autonomy and self-discipline and hindering misbehavior, which created an effective learning environment and well-managed classrooms. Similar findings were revealed by Saeed's study (2009) which showed that implementing proper instructional strategies made learning meaningful and interesting for the learners and resulted in an effective classroom management. On the other hand, in Demir's research study (2009) it was revealed that teachers could not engage learners in lessons as they did not adapt their classroom practices to facilitate classroom management and to create effective classroom atmosphere. Therefore, it can be inferred that the use of effective instructional strategies is the core of a well-managed classroom. As a good lesson planning is one of the most powerful preventive classroom management strategies, teachers should put time and effort into utilizing effective lesson planning and implementation techniques.

(4) As revealed by the analysis of the studies, classroom management was also affected by the motivational considerations during the learning process. In the same way, as indicated by the findings, it is apparently easier to manage the groups of students who are cognitively engaged, self-motivated and self-monitoring their behaviors. Considering these findings, it can be asserted that changing motives and expectations of the students in the new learning environments necessitate implementation of relevant and challenging instructional strategies that address learners' needs and ensure their full engagement. In this context, different aspects of use of technology were discussed as it relates to classroom management and students' motivation to learn in the reviewed studies. The new generation (2000-2001), named as the digital generation or the " $Z$ generation", is living in a digital era. Hence, technology is more compatible to the z-generation's socio-cultural environment (Bassiouni \& Hackley, 2014; Batı\& Ünal, 2011). When this is addressed within this context, learning with technology may have a more positive impact on students' learning motivation. Therefore, it can be recommended that teachers improve their pedagogical and subject area knowledge along with knowledge of technology to meet the needs of their learners in the contemporary classrooms.

The present study presented a systematic review of the qualitative research studies about classroom management. The study investigated the relationship between classroom management and students' learning by examining main findings of the reviewed studies in detail. Further research can be carried out to investigate different dimensions of classroom management through a meta-analysis of quantitative research. 


\section{REFERENCES}

Akar, H.,Tor, D., Tantekin Erden, F. \& Şahin, İ.T. (2010). Study on teachers' classroom management approaches and experiences. Elementary Education Online 9(2), 792-806.

Akar, H., \& Yildirim, A. (2009). Change in teacher candidates' metaphorical images about classroom management in a social constructivist learning environment. Teaching in Higher Education, 14(4), 401-415.

Akan, D., \& Basar, M. (2013). The effect of the classroom activities on classroom management in the teachinglearning process: The case of Uşak City. Mevlana International Journal of Education, 3(4). http://dx.doi.org/10.13054/mije.13.63.3.4

Akın S., Yıldırım, A., \& Lin Goodwin (2016). Classroom management through the eyes of elementary teachers in turkey: a phenomenological study. Educational Sciences: Theory \& Practice,16(3), 771-797 DOI: 10.12738/estp.2016.3.0376

Arın, E., Kızılaslan Tunçer, B., \& Demir, M. K. (2017). Primary school teachers' views on constructive classroom management. International Electronic Journal of Elementary Education, 8(3), 363-378.

Baker, C., Gentry, J., \& Larmer, W. (2016). A Model for Online Support in Classroom Management: Perceptions of Beginning Teachers. Administrative Issues Journal: Connecting Education, Practice, and Research, 6(1), 2237. DOI: $10.5929 / 2016.6 .1 .3$

Bassiouni, D. H., \& Hackley, C. (2014). 'Generation Z' children's adaptation to digital consumer culture: A critical literature review. Journal of Customer Behaviour, 13(2), 113-133.

Batı, U. \& Ünal, G. T. (2011). Sekizinci Sanatın İnşası: “Dijital Oyunlar Kesişiminde Postmodenizm, Tüketim Kültürü, Üst Gerçeklik, Kimlik ve Olağan Şiddet”. (s.3-33). Dijital Oyunlar: Kendi Dünyanda Yaşa, Bizimkinde Oyna, Istanbul: Der Publishing.

Bearman, M., Smith, C. D., Carbone, A., Slade, S., Baik, C., Hughes-Warrington, M., \& Neumann, D. L. (2012). Systematic review methodology in higher education. Higher Education Research \& Development, 31(5), 625640.

Bosch, K. A. (2006). Planning classroom management: A five-step process to creating a positive learning environment (2nd ed.). Thousand Oaks, CA: Sage

Boyac1, A. (2010). Pre-service teachers' views on web-based classroom management. The Turkish Online Journal of Distance Education, 11(2), 208-234

Brocato, K. (2009). Studio Based Learning: Proposing, Critiquing, Iterating Our Way to Person-Centeredness for Better Classroom Management. Theory Into Practice, 48(2), 138-146.

Broome, J. L. (2013). A case study in classroom management and school involvement: Designing an art room for effective learning. Art Education, 66(3), 39-46.

Brophy, J. (1988). Educating teachers about managing classrooms and students. Teaching and Teacher Education, 4 (1), 1-18.

Collier-Meek, M. A., Johnson, A. H., Sanetti, L. H., \& Minami, T. (2019). Identifying critical components of classroom management implementation. School Psychology Review, 48(4), 348-361. DOI: 10.17105/SPR-20180026.V48-4

Çandar, H. \& Şahin (2013), Teachers' views about effects of constructivist approach on classroom management. Hacettepe University Journal of Education, 44, 109-119.

Demir, S. (2009). Teacher perceptions of classroom management and problematic behaviors in primary schools. Procedia Social and Behavioral Sciences, 1, 584-589

Djigic G. \& Stojiljkovic, S. (2011). Classroom management style, classroom climate and school achivement. Procedia Social and Behavioral Sciences, 29,819-828.

Erdogan, M., Kursun, E., Sisman, G. T., Saltan, F., Gok, A., \& Yildiz, I. (2010). A qualitative study on classroom management and classroom discipline problems, reasons, and solutions: A case of information technologies class. Educational Sciences: Theory and Practice, 10(2), 881-891.

Ersozlu, A., \& Cayci, D. (2016). The changes in experienced teachers' understanding towards classroom management. Universal Journal of Educational Research, 4(1), 144-150. DOI: 10.13189/ujer.2016.040118

Evertson, C. M., \& Weinstein, C. S. (2006). Classroom management as a field of inquiry. In C. M. Evertson \& C. S. Weinstein (Eds.), Handbook of classroom management: Research, practice, and contemporary issues (pp. 3-16). Mahwah, NJ: Lawrence Erlbaum Associates

Foxworthy, J. E. (2006). Teachers' beliefs about classroom management. Unpublished Master's Thesis. Lakehead University, Canada. 
Freiberg, H. J., Huzinec, C. A. \& Templeton, S. M. (2009). Classroom management-a pathway to student achievement: A study of fourteen inner city elementary schools. The Elementary School Journal, 110(1), 63-80.

Garrett, T. (2008). Student-centered and teacher-centered classroom management: A case study of three elementary teachers. Journal of Classroom Interaction, 43(1), 34-47.

Guardino, C.A. \& Fullerton, E. (2010). Changing behaviors by changing the classroom environment. Teaching Exceptional Children, 42 (6), 8-13.

Glickman, C. \& Tamashiro, R. (1980). Classifying teachers' beliefs about discipline. Educational Leadership, 37 (6), 459-464.

Hardin, C. J. (2011). Effective classroom management: Models and strategies for today's classrooms. Pearson Higher Ed.

Hildenbrand, S. M., \& Arndt, K. (2016). Student teachers' management practices in elementary classrooms: a qualitative study. Teacher Development, 20(2), 147-161.

Khan, K., Khan, M. S. \& Majoka, M. I. (2011). Gender differences in classroom management strategies at secondary level. Interdisciplinary Journal of Contemporary Research in Business, 3(3), 580-589

Kubat, U., \& Dedebali, N. C. (2018). Opinions of science teachers for classroom management. Journal of Education and e-Learning Research, 5(2), 110-117. DOI: 10.20448/journal.509.2018.52.110.117

Kurawa, G. (2010). Teaching diversity in a primary school: examining teachers' classroom strategies for inclusion. Procedia - Social and Behavioral Sciences, 5, 1585-1591

Kunter, M., Baumert, J., \& Köller, O. (2007). Effective classroom management and the development of subjectrelated interest. Learning and Instruction, 17(5), 494-509.

Laut, J. (1999). Classroom management: beliefs of preservice teachers and classroom teachers concerning classroom management styles. Paper presented at the Fall Teachers Education Conference, Charleston, SC.

Lew, M. M., \& Nelson, R. F. (2016). New teachers' challenges: How culturally responsive teaching, classroom management, \& assessment literacy are intertwined. Multicultural Education, 23(3-4), 7-13

Mader, C. E. (2009). "I will never teach the old way again": Classroom management and external incentives. Theory into Practice, 48(2), 147-155.

Manning, M.,L \& Buthcer, K. T. (2003). Clasroom management: models applications and cases. New Jersey, Merril-Prentice-Hall.

Martin, N. \& Baldwin, B. (1992). Beliefs regarding classroom management style: Differences between novice and experienced teachers. Paper presented at the Annual Meeting of the Mid-South Educational Research Association. Knoxville, TN.

Martin, J., \& Sugarman, J. (1993). Models of classroom management: Principles, applications and critical perspectives (2nd ed.). Calgary, AB: Temeron Books.

Martin, N. \& Yin, Z. (1997). Attitudes and Beliefs regarding classroom management style: Differences between Male and Female Teachers. Paper presented at the Annual Meeting of the Southwest educational research Association, Austin, TX.

Martin, N., Yin, Z., \& Mayall, H. (2006). Classroom management training, teaching experience and gender: Do these variables impact teachers' attitudes and beliefs toward classroom management style? Paper presented at the annual conference of the Southwest Educational Research Association. Austin, TX.

Merç, A., \& Subaşı, G. (2015). Classroom management problems and coping strategies of Turkish student EFL teachers. Turkish Online Journal of Qualitative Inquiry, 6(1), 39-71.

Oyinloye, G.O. (2010). Primary school teachers' perceptions of classroom management and its influence on pupils' activities. European Journal of Educational Studies, 2(3), 305-312.

Paliç, G., \& Keleş, E. (2011). Sınıf yönetimine ilişkin öğretmen görüşleri. Educational Administration: Theory and Practice, 17(2), 199-220.

Poon, C.L., Tan, D. \& Tan A.L. (2009) Classroom management and inquiry-based learning: Finding the balance. Science Scope, 32(9), 18-21.

Saeed, S. (2009). Evaluation study of competencies of secondary school teachers in Punjab in the context of classroom management. Journal of College Teaching \& Learning (TLC), 6(7), 79-84

UNESCO. (2012). A place to learn: Lessons from research on learning environments (Technical paper No. 9). Montreal: United Nations Educational, Scientific and Cultural Organization, Institute for Statistics. Retrived from: 21.06.2020 https://unesdoc.unesco.org/ark:/48223/pf0000215468

Walters, J., \& Frei, S. (2007). Managing classroom behavior and discipline. CA: Shell Education. 
Webster-Stratton, C., Reinke, W. M., Herman, K. C., \& Newcomer, L. L. (2011). The incredible years teacher classroom management training: The methods and principles that support fidelity of training delivery. School Psychology Review, 40(4), 509-529.

Weinstein, C. S. \& Novodvorsky, I. (2015). Middle and secondary classroom management: lessons from research and practice. Boston: McGraw Hill.

Vors, O., \& Gal-Petitfaux, N. (2015). Relation between students' involvement and teacher management strategies in French 'difficult'classrooms. Physical Education and Sport Pedagogy, 20(6), 647-669.

Yıldırım, M. C. and Dönmez, B. (2008). A study about the effects of constructivist learning approach practices on classroom management. Elementary Education Online, 7(3), 664-679. 
APPENDIX A: ANALYZED THE RESEARCH STUDIES

\begin{tabular}{|c|c|c|c|}
\hline Researchers/Year/Title & Purpose & Participants & Research Method \\
\hline $\begin{array}{l}\text { Brocato, } 2009 \\
\text { Studio Based Learning: } \\
\text { Proposing, Critiquing, } \\
\text { Iterating Our Way to Person- } \\
\text { Centeredness for Better } \\
\text { Classroom Management }\end{array}$ & $\begin{array}{l}\text { To propose and } \\
\text { alternative model of } \\
\text { teaching about classroom } \\
\text { management: studio- } \\
\text { based learning. } \\
\text { To investigate students' } \\
\text { reaction to this } \\
\text { pedagogical approach and } \\
\text { to examine whether it } \\
\text { allows for person- } \\
\text { centeredness and foster } \\
\text { better thinking about } \\
\text { classroom management. }\end{array}$ & $\begin{array}{l}321 \text { student } \\
\text { teachers attending } \\
\text { to a course called } \\
\text { Planning for the } \\
\text { Diversity of } \\
\text { Learners }\end{array}$ & $\begin{array}{l}\text { Design Based Research } \\
\text { (triangulation of survey } \\
\text { and discourse analysis to } \\
\text { examine participants', } \\
\text { reaction to SBL along } \\
\text { with implementation of } \\
\text { SBL which necessitates } \\
\text { preparation of design } \\
\text { projects) }\end{array}$ \\
\hline $\begin{array}{l}\text { Mader, } 2009 \\
\text { "I will Never Teach the Old } \\
\text { Way Again": Classroom } \\
\text { Management and External } \\
\text { Incentives }\end{array}$ & $\begin{array}{l}\text { To experiment self- } \\
\text { grading as a way to } \\
\text { remove external } \\
\text { incentives and allow } \\
\text { students to experience } \\
\text { their own motivation } \\
\text { levels without outside } \\
\text { influence. } \\
\text { The instructor utilized } \\
\text { survey method to see the } \\
\text { perceptions of his } \\
\text { students regarding } \\
\text { removal of instructor } \\
\text { grading. }\end{array}$ & $\begin{array}{l}\text { Student teachers } \\
\text { attending a } \\
\text { graduate elective } \\
\text { course in } \\
\text { classroom } \\
\text { management }\end{array}$ & Action Research \\
\hline $\begin{array}{l}\text { Poon, Tan and Tan, } 2009 \\
\text { Classroom Management and } \\
\text { Inquiry Based Learning- } \\
\text { Finding the Balance }\end{array}$ & $\begin{array}{l}\text { To share seven successful } \\
\text { strategies one teacher } \\
\text { used in managing a sixth } \\
\text { grade class that gave her } \\
\text { confidence in } \\
\text { transitioning from a } \\
\text { traditional classroom to a } \\
\text { more inquiry-based } \\
\text { classroom. }\end{array}$ & $\begin{array}{l}\text { A Veteran teacher } \\
\text { and } 43 \text { students in } \\
\text { her class ( } 22 \text { girls } \\
\text { and } 21 \text { boys). }\end{array}$ & $\begin{array}{l}\text { Action Research } \\
\text { (Analysis of journal } \\
\text { entries of students) }\end{array}$ \\
\hline $\begin{array}{l}\text { Akar et. al,2010 } \\
\text { Study on Teachers' } \\
\text { Classroom Management } \\
\text { Approaches and Experiences }\end{array}$ & $\begin{array}{l}\text { To examine K-8 teachers' } \\
\text { classroom management } \\
\text { practices and their } \\
\text { experiences through a } \\
\text { qualitative study to } \\
\text { explore teachers' } \\
\text { classroom management } \\
\text { needs. }\end{array}$ & $\begin{array}{l}19 \text { teachers } \\
\text { teaching K-8 } \\
\text { classrooms (six } \\
\text { public }(n=9) \text { and } \\
\text { four private }(n=10)\end{array}$ & $\begin{array}{l}\text { A Qualitative research } \\
\text { design } \\
\text { Semi-structured } \\
\text { Interview }\end{array}$ \\
\hline $\begin{array}{l}\text { Boyac1, } 2010 \\
\text { Pre-Service Teachers' Views } \\
\text { on Web-Based Classroom } \\
\text { Management }\end{array}$ & $\begin{array}{l}\text { To find out views of pre- } \\
\text { service teachers } \\
\text { regarding web-based } \\
\text { classroom management }\end{array}$ & $\begin{array}{l}20 \text { pre-service } \\
\text { teachers attending } \\
\text { different programs } \\
\text { at Faculty of } \\
\text { Education in } \\
\text { Anadolu } \\
\text { University }\end{array}$ & $\begin{array}{l}\text { Qualitative Research } \\
\text { Method } \\
\text { Semi-structured interview }\end{array}$ \\
\hline $\begin{array}{l}\text { Erdoğan et. al, } 2010 \\
\text { A Qualitative Study on } \\
\text { Classroom Management and } \\
\text { Classroom Discipline } \\
\text { Problems, Reasons and } \\
\text { Solutions: A Case Study of }\end{array}$ & $\begin{array}{l}\text { To investigate classroom } \\
\text { management and } \\
\text { discipline problems that } \\
\text { Information Technology } \\
\text { teachers have and to } \\
\text { reveal underlying reasons } \\
\text { and possible solutions of }\end{array}$ & $\begin{array}{l}14 \text { school } \\
\text { administrators, } 14 \\
\text { teachers and } 17 \\
\text { parents. }\end{array}$ & $\begin{array}{l}\text { Qualitative Case Study } \\
\text { Semi-structured } \\
\text { Interview schedules }\end{array}$ \\
\hline
\end{tabular}




\begin{tabular}{|c|c|c|c|}
\hline $\begin{array}{l}\text { Information Technologies } \\
\text { Classrooms }\end{array}$ & $\begin{array}{l}\text { these problems by } \\
\text { considering the view of } \\
\text { parents, teachers and } \\
\text { administrators. }\end{array}$ & & \\
\hline $\begin{array}{l}\text { Guardino and Fullerton, } 2010 \\
\text { Changing Behaviors by } \\
\text { Changing the Classroom } \\
\text { Environment }\end{array}$ & $\begin{array}{l}\text { To explore the effect of } \\
\text { modifications in } \\
\text { classroom environment } \\
\text { on academic engagement } \\
\text { and disruptive behavior in } \\
\text { an inclusive classroom. }\end{array}$ & $\begin{array}{l}\text { An elementary } \\
\text { school teacher } \\
\text { teaching in an } \\
\text { urban area of } \\
\text { southeastern } \\
\text { United States. }\end{array}$ & $\begin{array}{lr}\text { Case Study } & \text { Follow-up } \\
\text { interview, } & \text { teacher } \\
\text { questionnaire } & \text { and } \\
\text { observation. } & \end{array}$ \\
\hline $\begin{array}{l}\text { Paliç and Keleş, } 2011 \\
\text { Teacher Opinions on } \\
\text { Classroom Management }\end{array}$ & $\begin{array}{l}\text { To explore opinions of } \\
\text { teachers working in } \\
\text { primary and secondary } \\
\text { schools with regard } \\
\text { classroom management' } \\
\text { in 'teacher } \\
\text { competencies', } \\
\text { 'approaches', 'classroom } \\
\text { management problems' } \\
\text { and 'suggestions' } \\
\text { dimensions. }\end{array}$ & $\begin{array}{l}42 \text { teachers } \\
\text { working at } \\
\text { primary and } \\
\text { secondary schools } \\
\text { in Rize }\end{array}$ & $\begin{array}{l}\text { Qualitative Research } \\
\text { Method } \\
\text { (Interview Technique) }\end{array}$ \\
\hline $\begin{array}{l}\text { Akan and Basar, } 2013 \\
\text { The effect of the classroom } \\
\text { activities on classroom } \\
\text { management in the } \\
\text { teaching- learning process: } \\
\text { The case of Uşak City }\end{array}$ & $\begin{array}{l}\text { To evaluate the effects of } \\
\text { the activities done by } 5 \text { th } \\
\text { grade primary school } \\
\text { teachers in the teaching } \\
\text { and learning process. }\end{array}$ & $\begin{array}{l}\text { Fifteen teachers } \\
\text { and thirty students }\end{array}$ & $\begin{array}{l}\text { Case study method. } \\
\text { Nonstructured } \\
\text { observations and } \\
\text { structured interviews }\end{array}$ \\
\hline $\begin{array}{l}\text { Broome, } 2013 \\
\text { A Case Study in Classroom } \\
\text { Management and School } \\
\text { Involvement: Designing an } \\
\text { Art Room for Effective } \\
\text { Learning }\end{array}$ & $\begin{array}{l}\text { To investigate } \\
\text { preventative measures } \\
\text { through the lens of a } \\
\text { uniquely selected art } \\
\text { educators }\end{array}$ & An art teacher & $\begin{array}{l}\text { Case Study } \\
20 \text { hours of field } \\
\text { observations and three } \\
\text { interviews }\end{array}$ \\
\hline $\begin{array}{l}\text { Çandar and Şahin, } 2013 \\
\text { Teachers' Views about Effects } \\
\text { of Constructivist Approach on } \\
\text { Classroom Management }\end{array}$ & $\begin{array}{l}\text { To determine the possible } \\
\text { effects of the } \\
\text { constructivist approach } \\
\text { applied by teachers, on } \\
\text { classroom management. }\end{array}$ & $\begin{array}{l}20 \text { teachers } \\
\text { working in } \\
\text { Şereflikoçhisar, } \\
\text { Ankara }\end{array}$ & $\begin{array}{l}\text { Qualitative Research } \\
\text { Semi-structured } \\
\text { Interview }\end{array}$ \\
\hline $\begin{array}{l}\text { Merç and Subaş1, } 2015 \\
\text { Classroom Management } \\
\text { Problems and Coping } \\
\text { Strategies of Turkish Student } \\
\text { EFL Teachers }\end{array}$ & $\begin{array}{l}\text { To determine the eliciting } \\
\text { problems, coping } \\
\text { strategies, and the sources } \\
\text { of those coping strategies } \\
\text { related to CM during } \\
\text { teaching } \\
\text { practicum. }\end{array}$ & $\begin{array}{l}12 \text { student EFL } \\
\text { teachers }\end{array}$ & $\begin{array}{l}\text { Qualitative } \\
\text { design } \\
\text { Journals } \\
\text { Field Notes } \\
\text { Interviews }\end{array}$ \\
\hline $\begin{array}{l}\text { Lew and Nelson, } 2016 \\
\text { New teachers' challenges: } \\
\text { How culturally responsive } \\
\text { teaching, classroom } \\
\text { management, \& assessment } \\
\text { literacy are intertwined. }\end{array}$ & $\begin{array}{l}\text { To investigate classroom } \\
\text { management practices of } \\
\text { novice teachers. } \\
\text { To examine conceptual } \\
\text { understanding } \\
\text { of culturally responsive } \\
\text { teaching among } \\
\text { new teachers }\end{array}$ & $\begin{array}{l}16 \text { new teachers } \\
\text { who graduated } \\
\text { from the teacher } \\
\text { education program } \\
\text { in the last two } \\
\text { years. }\end{array}$ & $\begin{array}{l}\text { Qualitative research } \\
\text { design } \\
\text { Face-to-face interviews } \\
\text { Participants were asked to } \\
\text { self-assess their level of } \\
\text { effectiveness in the areas } \\
\text { of CRT, classroom } \\
\text { management, and } \\
\text { classroom assessment }\end{array}$ \\
\hline
\end{tabular}

\begin{tabular}{llll}
\hline Vors and Gal- Petitfaux, 2015 & $\begin{array}{l}\text { To investigate the } \\
\text { relations between the } \\
\text { students' motor and } \\
\text { social involvement and }\end{array}$ & $\begin{array}{l}\text { Four experienced } \\
\text { physical education } \\
\text { Relation between students } \\
\text { involvement and teacher }\end{array}$ & $\begin{array}{l}\text { The cognitive } \\
\text { anthropology framework } \\
\text { of 'course of action'. }\end{array}$
\end{tabular}




\begin{tabular}{|c|c|c|c|}
\hline $\begin{array}{l}\text { management strategies in } \\
\text { French 'difficult' classrooms }\end{array}$ & $\begin{array}{l}\text { the class management } \\
\text { strategies }\end{array}$ & & $\begin{array}{l}\text { Observations and } \\
\text { interviews }\end{array}$ \\
\hline $\begin{array}{l}\text { Akın, Y1ldırım and Goodwin, } \\
2016 \\
\text { Classroom Management } \\
\text { through the Eyes of } \\
\text { Elementary Teachers in } \\
\text { Turkey: A Phenomenological } \\
\text { Study }\end{array}$ & $\begin{array}{l}\text { To explore Turkish } \\
\text { elementary teachers' (1) } \\
\text { perceptions of classroom } \\
\text { management, } \\
\text { (2)classroom } \\
\text { management problems } \\
\text { they experience, } \\
\text { (3)factors causing these } \\
\text { problems, and (4) their } \\
\text { classroom management } \\
\text { practices }\end{array}$ & $\begin{array}{l}15 \text { elementary } \\
\text { teachers }\end{array}$ & $\begin{array}{l}\text { Phenomenological } \\
\text { research design } \\
\text { Semi-structured } \\
\text { interviews }\end{array}$ \\
\hline $\begin{array}{l}\text { Baker, Gentry and Larmer, } \\
2016 \\
\text { A Model for Online Support } \\
\text { in Classroom Management: } \\
\text { Perceptions of Beginning } \\
\text { Teachers }\end{array}$ & $\begin{array}{l}\text { To assess the perceptions } \\
\text { of beginning teachers in } \\
\text { response to a model of } \\
\text { professional development } \\
\text { that included a workshop } \\
\text { on classroom } \\
\text { management coupled } \\
\text { with extended online } \\
\text { support for the } \\
\text { application of } \\
\text { management methods } \\
\text { taught in the workshop }\end{array}$ & $\begin{array}{l}\text { Six beginning } \\
\text { teachers in their } \\
\text { first or second year } \\
\text { of teaching }\end{array}$ & $\begin{array}{l}\text { Researchers followed } \\
\text { open and axial coding } \\
\text { methodology and peer } \\
\text { debriefing to determine } \\
\text { themes and patterns with } \\
\text { the narrative data }\end{array}$ \\
\hline $\begin{array}{l}\text { Ersozlu and Çayc1,2016 } \\
\text { The Changes in Experienced } \\
\text { Teachers' Understanding } \\
\text { towards Classroom } \\
\text { Management }\end{array}$ & $\begin{array}{l}\text { To examine the views of } \\
\text { experienced teachers } \\
\text { related to the changes in } \\
\text { their understanding of } \\
\text { classroom management in } \\
\text { general terms until today }\end{array}$ & 23 teachers & $\begin{array}{l}\text { Qualitative research } \\
\text { Semi-structured } \\
\text { interview form. Interview }\end{array}$ \\
\hline $\begin{array}{l}\text { Hildenbrand and Arndt, } 2016 \\
\text { Student teachers' } \\
\text { management practices in } \\
\text { elementary classrooms: a } \\
\text { qualitative study }\end{array}$ & $\begin{array}{l}\text { To establish a community } \\
\text { of practice and } \\
\text { To examine student } \\
\text { teachers' beliefs, } \\
\text { understanding, and } \\
\text { challenge of elementary } \\
\text { classroom management } \\
\text { strategies. }\end{array}$ & $\begin{array}{l}\text { Four student } \\
\text { teachers }\end{array}$ & $\begin{array}{l}\text { Qualitative study } \\
\text { Survey, observations, } \\
\text { audio transcripts of } \\
\text { seminar meetings, and } \\
\text { written reflections. }\end{array}$ \\
\hline $\begin{array}{l}\text { Arın, Kilıçarslan Tunçer and } \\
\text { Demir, } 2017 . \\
\text { Primary School Teachers' } \\
\text { Views on Constructive } \\
\text { Classroom Management }\end{array}$ & $\begin{array}{l}\text { To determine the } \\
\text { characteristics of a } \\
\text { classroom where } \\
\text { constructive classroom } \\
\text { management is practiced } \\
\text { and how this differs from } \\
\text { those where the } \\
\text { traditional approach is } \\
\text { adopted. }\end{array}$ & $\begin{array}{l}175 \text { primary } \\
\text { school teachers }\end{array}$ & $\begin{array}{l}\text { A phenomenological } \\
\text { research design } \\
\text { Standardized open-ended } \\
\text { interviews }\end{array}$ \\
\hline $\begin{array}{l}\text { Kubat and Dedebali, } 2018 . \\
\text { Opinions of Science Teachers } \\
\text { for Classroom Management }\end{array}$ & $\begin{array}{l}\text { To investigate science } \\
\text { teachers' concerns about } \\
\text { how to achieve effective } \\
\text { classroom management, } \\
\text { with particular reference } \\
\text { to classroom } \\
\text { communication, student } \\
\text { motivation, physical } \\
\text { environments and }\end{array}$ & $\begin{array}{l}14 \text { science } \\
\text { teachers }\end{array}$ & $\begin{array}{l}\text { Aqualitative research } \\
\text { method and } \\
\text { phenomenological design } \\
\text { The semi-structured } \\
\text { interview }\end{array}$ \\
\hline
\end{tabular}


unwanted student

behaviors.

Collier-Meek, and

Minami,2019

Identifying Critical

Components of Classroom

Managemen Implementation
To evaluats the relationship between elementary school teachers' implementation of specific classroom management components and class-wide academic engagement.
Ten teachers and Exploratory study their students $(N=$ Observations 177) 


\section{GENIŞLETILMIŞ ÖZET}

\section{Giriş}

Çağdaş sınıflarda öğretmenler, öğrencilerin 21. yüzyılda başarılı olabilmeleri için gerekli beceri ve yetkinlikleri kazanmalarına olanak sağlayacak verimli öğrenme ortamı oluşturabilmelidir. Sınıfta verimli ve olumlu bir öğrenme ortamı oluşturabilmek öğretmenler için zorlu bir görevdir çünkü gerçek sınıf ortamında öğrenmeyi olumlu ya da olumsuz şekilde etkileyen çeşitli faktörler vardır (Hardin, 2011; Weinstein \& Novodvorsky, 2015). Dersin akışını olumsuz etkileyen ve öğrenme-öğretme ortamını bozan istenmeyen öğrenci davranışları, sınıf yönetiminde önemli bir sorunun göstergesidir. Öğrencilerin problemli davranışları önemli ölçüde ders sırasında zaman kaybına neden olması ve öğrenme sürecini olumsuz etkilemesi nedeniyle önemli eğitim ve öğrenim sorunları arasındadır. Dolayısıyla öğretmenlerin bu sorunlarla baş edebilme becerilerine sahip olmaları gerekmektedir. Bununla birlikte öğrencilerin ne kadar etkili öğrendiklerini, becerilerini ne kadar iyi geliştirdiklerini ve sınıfta ne kadar iyi davranış sergilediklerini belirleyen en önemli faktörler arasında da öğretmenin sınıf yönetimi becerileri yer almaktadır (Oyinloye, 2010). Literatürdeki sınıf yönetimi tanımları ve daha önce yapılan araştırmalar, sınıf yönetimi ile öğrenme ve akademik başarı arasındaki ilişkiyi vurgulamaktadır. Literatür incelendiğinde nitel araştırma yöntemlerinin kullanıldığı araştırmaların sistematik bir analizi yoluyla sınıf yönetimi ve öğrenme arasındaki ilişkiyi inceleyen bir çalışmaya rastlanılmamıştır. $\mathrm{Bu}$ çerçevede, bu araştırma ile sınıf yönetimine ilişkin güncel bakış açılarının ve uygulamalarının bir sentezi yapılıp, varsa etkisiz sınıf yönetimi uygulamalarından kaynaklanan eğitim/öğrenme sorunlarına çözüm getirilmesine katkı sağlamak amaçlanmaktadır.

\section{Amaç}

$\mathrm{Bu}$ çalışmanın temel amacı, 2009-2019 yılları arasında sınıf yönetimi konusunda yapılan nitel çalışmaları sistematik bir şekilde değerlendirmektir. Ayrıca, sınıf yönetimi ile öğrenme arasındaki ilişkinin, sınıf yönetimine dair güncel bakış açıları ve uygulamaları incelenerek araştırılması amaçlanmıştır. Bu sistematik değerlendirme, aşağıdaki soruları yanıtlamayı amaçlamıştır:

1) İncelenen araştırmaların bulgularında ne tür ortak temalar ortaya çıkmaktadır?

2) İncelenen araştırmaların sınıf yönetimi ve öğrenmeye ilişkin ana bulguları nelerdir?

\section{Metodoloji}

$\mathrm{Bu}$ araştırmada sistematik değerlendirme yöntemi kullanılmıştır. Sistematik değerlendirme, araştırmaların kaliteli bir sentezinin yapılması yoluyla politika ve uygulamalar için anlamlı çıkarımlar sağlayan bir yöntemdir (Bearman vd. 2012). Sistematik değerlendirme süreci, belirli kriterler doğrultusunda araştırmaların detaylı analizlerinin yapılmasını ve karşılaştırılmasını gerektirmektedir. Bu çalışmada sınıf yönetimi ve öğrenme arasındaki ilişkiyi incelemek için sınıf yönetimi konusunda yapılan araştırmalar incelenmiştir. Araştırmalara EBSCOHOST eğitim veritabanı METUnique Search ile taranarak erişilmiştir. Dâhil edilme ve dişlanma kriterleri doğrultusunda 21 araştırma sistematik değerlendirme sürecine alınmıştır. Sınıf yönetimi ile ilgili nitel verilerin sistematik bir şekilde sentezlenmesi, öğrenme ve sınıf yönetimi ile ilgili ortak temaların oluşturulması amacıyla incelenen araştırmaların ana bulgularının içerik analizi yapılmıştır.

\section{Sonuç ve Tartışma}

Yapılan sistematik değerlendirmenin sonuçları sınıf yönetimi ve öğrenmenin dört ana tema çerçevesinde incelendiğini göstermiştir: "olumlu öğrenme ortamı," "sinıfin fiziksel ortamı," "öğrenme görevlerinin ve ögretim etkinliklerinin yönetimi" ve "motivasyon ve akademik katılım." Olumlu öğrenme ortamı teması çevresindeki bulgular sınıf yönetiminin çoğunlukla olumlu bir öğrenme ortamı yaratma ile ilişkili olduğunu ortaya koymuştur. İncelenen çalışmalarda, olumlu öğrenme ortamının oluşturulması ve sürdürülmesi sınıf yönetiminin önemli bir boyutu olarak gösterilmiştir. Ayrıca, incelenen çalışmalar öğretmenlerin sınıflarında olumlu bir iklim yaratma becerilerini geliştirmek için desteğe ihtiyaç duyduklarına işaret etmektedir. Sınıfın fiziksel ortamının öğrenme süreci üzerindeki etkisine ilişkin önemli bulgular ortaya çıkmıştır. Sınıfın fiziksel ortamı, öğrencilerin öğrenme sürecini ve sınıfta sergiledikleri davranışları şekillendirmektedir. Araştırmalar, sınıf tasarımlarının ve fiziksel özelliklerinin, öğrencilerin katılımını ve psikolojik iyi olma halini artırdığını, istenmeyen davranışları azaltarak öğrenmeyi olumlu yönde etkilediğini göstermiştir. Örneğin, sınıfın uygun olmayan fiziksel ortamı öğrenci merkezli etkinliklerde materyallerin etkili kullanımını engellemektedir (Akar vd., 2010). 
Öğretmenler sınıfı düzenli, temiz ve rahat hale getirdiklerinde öğrenciler derslere daha aktif katılım sağlamakta ve sınıf yönetimi olumlu yönde etkilenmektedir (Akın, Yıldırım ve Goodwin, 2013). "Öğrenme görevlerinin ve öğretim etkinliklerinin yönetimi” boyutunda elde edilen bulgulara göre, öğrencilere görev vermek öğrenci katılımını arttırıp öğrenciler arasında işbirliğini güçlendirerek sınıf yönetimi olumlu yönde etkilemektedir (Akan ve Başar, 2013; Lew ve Nelson, 2016). İncelenen araştırmalar, öğretmenlerin uygun öğretim yöntem ve stratejileri kullanarak tasarladıkları öğrenme görevleri uygulamaları gerektiğini göstermiştir. Çünkü bu tür etkinlikler akademik faaliyetlere harcanan zamanın artmasına ve istenmeyen davranışların engellenmesine katkıda bulunmaktadır. Sınıf yönetimi öğrenme sürecinde öğrenci motivasyonunu şekillendiren faktörlerden de etkilenmektedir. Bilişsel bağlılığı yüksek, kendi kendini motive edebilen ve kendi davranışlarını takip edebilen öğrenci gruplarını yönetebilmek çok daha kolaydır. Dolayısıyla, etkili bir sınıf yönetiminin var olması için öğrencilerin ihtiyaçlarına hitap eden ve onların tam katılımını sağlayan etkinliklerin uygulanması önem taşımaktadır. Araştırmanın sonuçları ışığında, öğretmen yetiştirme programlarının öğretmen adaylarının sınıflarında olumlu bir öğrenme ortamı oluşturabilmeleri yönünde rehberlik etmesi gerektiği söylenebilir. $\mathrm{Bu}$ kapsamda, öğretmen eğitiminin öğretmen adaylarına etkili sınıf yönetimi becerileri edindirmek amacıyla kuramsal bilgi ve uygulamayı bütünleştiren bir anlayışla ele alınması etkili olabilir. Benzer şekilde, öğretmenlerin ve öğretmen adaylarının sınıfın fiziksel ortamını öğretim amaçlarını ve öğrenci ihtiyaçlarını karşılayacak şekilde düzenleyebilmek; etkili ders planlama, uygulama ve öğretim tekniklerini kullanabilmek için zaman ve çaba harcama yönünde bilinçlendirilmesi önerilebilir. Araştırmacılara ise sınıf yönetimi konusunda yapılan nicel çalışmaların meta-analizinin yapılması önerilmektedir. 